[пер. с нем. Ю.Г. Жукова]. - М.: Финансы и статистика, 2004. - 304 с.

5. Райхман Т. Менеджмент и контроллинг. Одни цели - разные пути и инструменты / Пер. с нем. // Международный бухгалтерский учет. — 1999. — № 5 .

6. Фольмут Х.Й. Инструменты контроллинга от А до Я / Х.Й. Фольмут: [пер. с нем.]. - [под ред. и с предисл. М.Л. Лукашевича и Е.Н. Тионенковой]. - М.: Финансы и статистика, 2003. -288 с.

7. Хан Д. Планирование и контроль: концепция контроллинга / Д. Хан; [пер. с нем. под ред. А.А. Турчака, Л.Г. Головача, М.Л. Лукашевича]. - М.: Финансы и статистика, 1997. - 800 с.

8. Хорват П. Концепция контроллинга: Управленческий учет. Система отчетности. Бюджетирование: [текст] / Horvat\&Partners; - [пер. с нем. 2-е изд.] - М.: Альпина Бизнес Букс, 2006. - 269 с.

9. Shneider, D. Jnvestition. Finanzierung und Betreung. - Wiesbaden, 1992. — $258 \mathrm{c}$.

10. Азаренков Г.Ф. Можливості контролінгу в системі управління інноваційним розвитком підприємства / Г.Ф. Азаренков, О.Г. Зима, О.В. Писарчук // Проблеми економіки. - 2010. - №4 - С. 7478.

11. Аксентюк М.М. Формування адаптивної системи контролінгу в менеджменті аграрних підприємств: автореф. дис. на здобуття наукового ступеня к.е.н. за спеціальністю 08.00 .04 / М. М. Аксентюк. - Київ, 2008. - 21 с.

12. Ананькина Е.А. Контроллинг как инструмент управления предприятием / Е. А. Ананькина, С.В. Данилочкина, Н.Г. Данилочкина. М.: Аудит, ЮНИТИ, 1998. - 279 с.

13. Карминский А.М., Фалько С.Г., Жевага А. А., Иванова Н.Ю. Контроллинг. М: Финансы и статистика, 2006.- 336 с. 21.09.2011

14. Малышева Л. Контроллинг на предприятии // Открытые системы. М., №№1-2, 2000 , www.osp.ru
15. Потоцкая Е. Г. Организация и функционирование банковского контроллинга в системе внутреннего контроля // Бухгалтерия и банки. -M, №5,2001

16. Фалько С.Г., Левин Л.Ф. Контроллинг: национальные особенности - российский и американский опыт // Контроллинг. М., №2, 2009.

17. Чобіток B.I. Контролінгові механізми управління потенціалом конкурентоспроможності підприємств / B.I. Чобіток // Бізнес Інформ. - 2011. №12. - С. 162-164.

18. Шиманаев Н.Г. Применение процессного подхода в системе финансового контроллинга, http://nickgs.narod.ru/sngc02.html

19. Краткий экономический словарь / под ред. А.Н. Азрилияна. - М.: Институт новой экономики, 2001. $-966 \mathrm{c}$

20. Амосов О.Ю. Контролінгові механізми в системі управління підприємством / О.Ю. Амосов // Економіка та управління. - 2012. - №1. - С. 82-86.

21. Григораш I.O. Формування та розвиток системи управління підприємством на засадах контролінгу: автореф. дис. на здобуття наукового ступеня к.е.н. за спеціальністю 08.00 .04 / I.O. Григораш. - Київ, 2012. - 21 с.

22. Пушкар М.С. Контролінг - інформаційна підсистема стратегічного менеджменту: Монографія / М.С. Пушкар, Р.М. Пушкар. - Тернопіль: Карт-бланш, 2004. $-370 \mathrm{c}$.

23. Сухарева Л.А. Контроллинг - основа управления бизнесом / Л.А. Сухарева, С.Н. Петренко. К.: Эльга, Ника-Центр, 2002. - 208 с.

24. Терещенко О.О. Контролінг у системі антикризового управління підприємством / О.О. Терещенко // Фінанси України. - 2001. - №12. - С. 5663.

Рецензент д.е.н., професор ХІФ УДУФМТ Дороченко Г.О. Експерт редакційної колегії к.е.н., дочент УкрДАЗТ Полякова О.М.

УДК 658.012.1

\title{
МЕХАНІЗМ ВПРОВАДЖЕННЯ СИСТЕМИ КОНТРОЛІНГУ НА ВІТЧИЗНЯНИХ ПІДПРИЕМСТВАХ
}

\author{
Прохорова В. В., д.е.н., професор, \\ Баранівська С. В., масістр (УІПА)
}

У статті запропоновано та обтрунтовано методику дочільності впровадження системи контролінгу на вітчизняних підприємствах, розроблено етапи впровадження системи контролінгу на вітчизняних підприємствах, запропоновано механізм реалізачії контролінгу на вітчизняних підприємствах, визначено передумови необхідності впровадження системи контролінгу в діяльність вітчизняних підприємств, визначено фактори, щчо підтверджують необхідність впровадження системи контролінгу

(C) Прохорова В.В., Баранівська С.В.
Вісник економіки транспорту і промисловості № 49,2015 
на вітчизняних підприємствах, визначено вплив системи контролінгу на ефективність діяльності підприсмств та забезпечення конкурентоспроможності на вітчизняному ринку. Застосування контролінгу означає послідовне проведення ряду кроків, ефективність кожного з яких можна оцінити відразу після їх здійснення. Таким чином, впровадження системи контролінгу на підприємстві дуже важливо для ефективної роботи, так як ие дозволить раціонально використовувати ресурси підприємства. Впровадження системи контролінгу на підприємстві спрямовано на майбутнє, тобто ії завданням є не лиме звіт про фактично здійснені витрати або отримані прибутки, а забезпечення підприємства повною і якісною інформаџією для прийняття рішень щзодо планування майбутніх доходів $i$ вumpam.

Ключові слова: контролін, управлінські рішення, ефективність, функціонування, впровадження системи контролінгу, вітчизняні підприємства.

\title{
МЕХАНИЗМ ВНЕДРЕНИЯ СИСТЕМЫ КОНТРОЛИНГА НА ОТТЕЧЕСТВЕННЫХ ПРЕДПРИЯТИЯХ
}

\author{
Прохорова В. В., д.э.н., професор, \\ Барановская С. В., магистр (УИПА)
}

В статье предложено и обосновано методику целесообразности внедрения системь контроллинга на отечественных предприятиях, разработаны этапы внедрения системы контроллинга на отечественных предприятиях, предложен механизм реализации контроллина на отечественных предприятиях, определены предпосылки необходимости внедрения системы контроллина в деятельность отечественных предприятий, определены факторы, подтверждающие необходимость внедрения системы контроллинга на отечественных предприятиях, определено влияние системы контроллинга на эффективность деятельности предприятий и обеспечение конкурентоспособности на отечественном рынке. Применение контроллинга означает последовательное проведение ряда шагов, эффективность каждого из которых можно оценить сразу после их осуществления. Таким образом, внедрение системы контроллинга на предприятии очень важно для эффективной работы, так как это позволит рационально использовать ресурсы предприятия. Внедрение системы контроллинга на предприятии направлено на будущее, то есть ее задачей является не только отчет о фактически осуществленнье расходы или полученные доходы, а обеспечение предприятия полной и качественной информации для принятия решений по планированию будущих доходов и расходов.

Ключевые слова: контроллинг, управленческие решения, эффективность, функционирование, внедрение системы контроллинга, отечественные предприятия.

\section{MECHANISM OF INTRODUCTION THE SYSTEM OF CONTROLLING IN DOMESTIC ENTERPRISES}

\author{
Prohorova V. V., d.e.s., professor, \\ Baranovskaya S. V., MA (UEPA)
}

The paper proposes a method and proved feasibility of introducing a system of controlling at domestic enterprises developed stages of implementation of the controlling system of domestic enterprises, the mechanism for controlling the implementation of domestic enterprises and the introduction of necessary preconditions in controlling the activities of domestic enterprises and the factors justifying the need for the introduction of Controlling for domestic enterprises, the influence of the system of controlling the efficiency of enterprises and competitiveness in the domestic market. Applying a consistent means of controlling a series of steps, each of which effectiveness can be assessed immediately after their implementation. Thus, the introduction of controlling in the enterprise is very important for efficient operation, as it will allow rational use of resources of the enterprise. Implementation of controlling the company focused on the future, that is, its task is not only to report on actual expenditures made or received income and provide businesses with full and quality information for decisionmaking on planning of future income and expenses.

Keywords: controlling, management decisions, efficiency, performance, introduction of controlling domestic enterprises.

$\begin{array}{ccccc}\text { Постановка } & \text { проблеми. } & \text { Найбільш } & \text { підприємств, що працюють в сучасних умовах } \epsilon \\ \text { актуальним } & \text { завданням } & \text { для } & \text { вітчизняних } & \text { створення теоретичної бази і заснованого на ній }\end{array}$

Вісник економіки транспорту і промисловості № 49, 2015 
інструментарію, що допоможе модернізувати організаційну, виробничу і інформаційну структуру підприємства для вирішення проблем їх розвитку, що є гарантією стабільних успіхів не тільки в сьогоденні, але й в майбутньому. Одним 3 таких інструментів досягнення цієї мети є контролінг.

У даний час існує необхідність впровадження системи контролінгу на багатьох вітчизняних підприємствах, оскільки зберігаються проблеми в області управління, а саме: низька оперативність інформації; процес планування від виробництва, а не від збуту продукції; поєднання понять управління прибутком i управління грошовими потоками; складнощі 3 розділенням змінних і постійних витрат; відсутність контролю за досягненням цілей підприємства; недолік інформації для ухвалення управлінських рішень; низька культура аналізу досягнення цілей.

Аналіз останніх наукових досліджень $\boldsymbol{i}$ публікацій. У фундаментальних працях вітчизняних та зарубіжних вчених достатньо грунтовно досліджені питання, які пов'язані із загальними процесами впровадження системи контролінгу на підприємствах, зокрема: О.Ф. Балацького [1], О. О. Веклича [2], I. Є. Давидовича [3], Т. В. Калайтана [4], О. В. Портної [5], М. Н. Пушкара [6], Г. В. Савицької [7], О. О. Терещенка [8], P.А. Фатхудинова [9], В. І. Чобіток [11] та інших.

Але аналіз фундаментальних праць свідчить, те, що розробки, щодо розробки та впровадження системи контролінгу на вітчизняних підприємствах недостатньо висвітлені і потребують додаткових досліджень.

Виділення невирішених частин загальної проблеми. Питання розробки механізму впровадження системи контролінгу на вітчизняних підприємствах потребує додаткових досліджень, оскільки, саме контролінг виступає одним із важливих інструментів, що зможе забезпечити підвищення рівня їх конкурентоспроможності на вітчизняному та зарубіжних ринках.

Метою cmammi є формування та розробка механізму впровадження системи контролінгу на вітчизняних підприємствах в сучасних умовах господарювання.

Виклад основного матеріалу дослідження. Сучасний стан світового ринку характеризується постійними змінами умов в яких функціонують вітчизняні підприємства, що веде не просто до зростання ролі управління ним, а до якісних змін у розумінні його принципів, елементів структури і методів реалізації. У цих жорстких умовах перед керівниками вітчизняних підприємств особливо гостро постає задача передбачення i прогнозування розвитку ринкової ситуації i формування ефективних управлінських рішень 3 урахуванням впровадження системи контролінгу з $\begin{array}{llll}\begin{array}{l}\text { метою підвищення } \\ \text { конкурентоспроможності. }\end{array} & \text { рівня } & \text { ï } \\ \text { Впровадження системи } & \text { контролінгу } & \text { на }\end{array}$ вітчизняних підприємствах потребує часу. Досвід зарубіжних підприємств свідчить про поступовий розвиток цієї системи та про необхідність проходження періоду в декілька десятиліть, протягом яких в країні буде сформовано модель контролінгу. В наш час в Україні продовжується інтенсивна ідентифікація контролінгу в рамках концепції, яка б задовольнила потреби вітчизняних підприємств. Проте, при спробах чіткого визначення системи контролінгу на основі багатьох концепцій. Часткова проблема може полягати в тому, що в теорії остаточно не сформувалася думка щодо системи контролінгу [10].

Тенденції розвитку науки управління вітчизняними підприємствами зумовили враховувати те,що кожне підприємство функціонуючи стабільно чи 3 кризовими симптомами, має враховувати неминучість виникнення кризових ситуацій, які можуть призвести до збоїв у їх роботі або до серйозної дестабілізації та постійно оновлювати окремі функціональні елементи управління на засадах системи контролінгу [11].

Впровадження системи контролінгу на вітчизняних підприємствах спрямовано на майбутнє, тобто іiі завданням $є$ не лише звіт про фактично здійснені витрати або отримані прибутки, a забезпечення підприємства повною i якісною інформацією для продукування та прийняття рішень щодо планування майбутніх доходів і витрат.

Необхідність впровадження контролінгу в діяльність вітчизняних підприємств обумовлена наступним вимогами:

законодавчими (формування пакету нормативних та законодавчих документів, що забезпечують економічну свободу в рамках податкового законодавства);

теоретичними (трансформація вітчизняної обліково-аналітичної і економічної школи; адаптація закордонного обліку до вітчизняної теорії і практики);

практичними (необхідність впровадження якісно нових технологій управляння підприємством 3 метою адаптації системи управління підприємством до мінливих умов господарювання; підвищення конкуренції на ринку України; достатній рівень ресурсного забезпечення більшості підприємств України; поява керівників 3 «новим» мисленням; орієнтація діяльності підприємств на маркетинг).

Впровадження контролінгу на сучасних вітчизняних підприємствах підтверджується такими об'єктивними факторами: 
посилення нестабільності зовнішнього середовища висуває додаткові вимоги до системи управління підприємством;

ускладнення систем управління підприємством потребує механізму координації всередині системи управління;

інформаційний бум за нестачі релевантної інформації вимагає побудови спеціальної системи інформаційного забезпечення управління;

прагнення до системності, синтезу, інтеграції різних галузей знання та людської діяльності.

Можна виділити чотири етапи впровадження системи контролінгу на вітчизняних підприємствах: мета; впровадження на підприємстві управлінського обліку і звітності; впровадження процедур планування; впровадження процедур i механізмів контролю.

Отже, впровадження системи контролінгу відіграє дуже важливу роль в системі управління вітчизняних підприємств, яка $€$ однією із найсучасніших i ефективних систем. Вона $\epsilon$ відособленою системою, економічна сутність якої полягає в динамічному процесі перетворення та інтеграції існуючих методів обліку, аналізу, планування, контролю i координації в єдину систему отримання, обробки інформації для прийняття на його основі ефективних управлінських рішень, орієнтованих на досягнення результатів.

Впровадження системи контролінгу надасть можливість вітчизняним підприємствам вийти 3 кризового стану, дозволить досягти ефективного управління, створити й оцінити потенціал підрозділів підприємства, дослідити ідеї конкурентів, здійснити порівняльний аналіз отриманих результатів, використовувати інновації та інше.

Роль i значення впровадження системи контролінгу на вітчизняних підприємствах має визначатися ступенем необхідності сформованої інформації даною системою (рис.1).

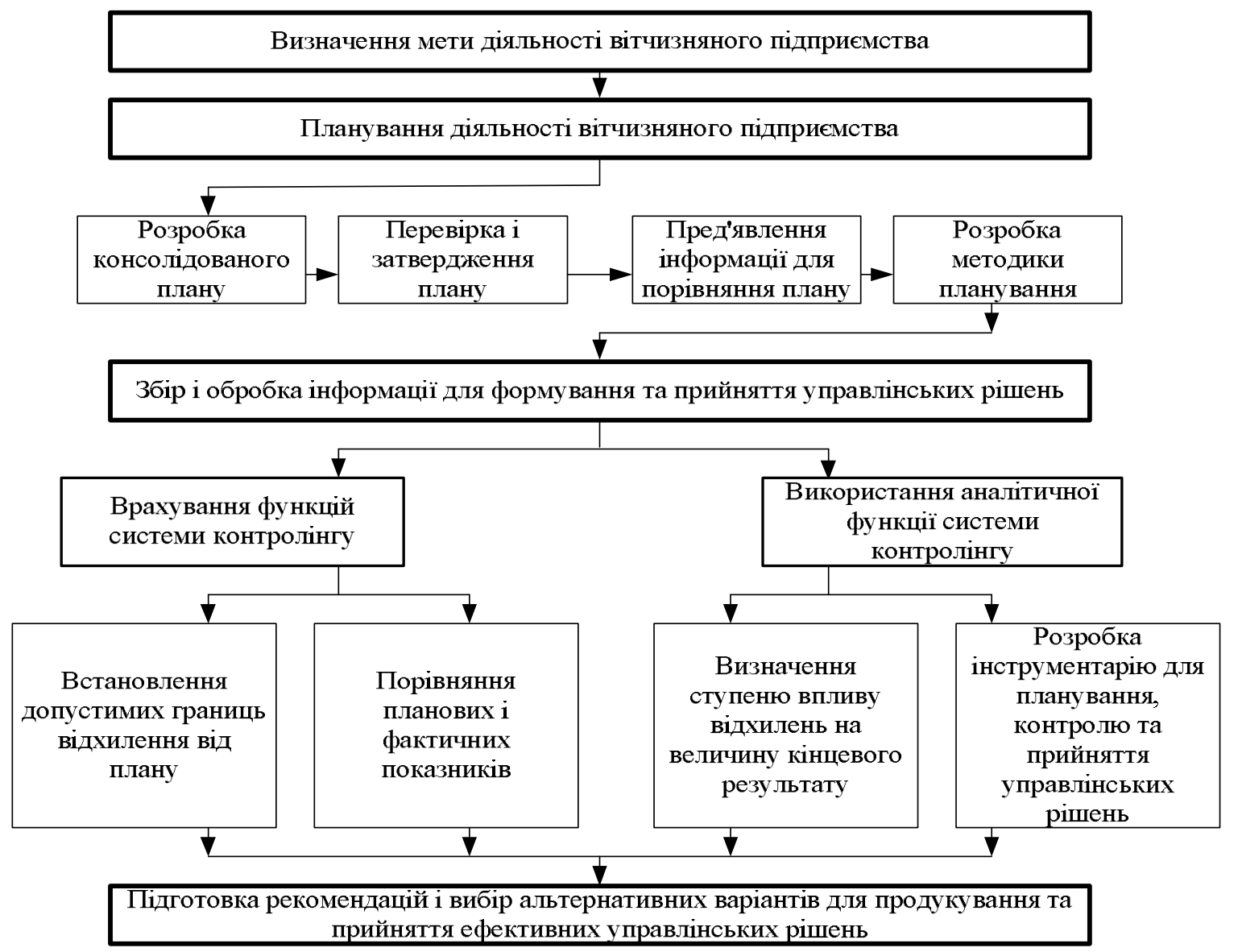

Рис.1. Схема впровадження системи контролінгу на вітчизняних підприємствах

Для ефективного впровадження системи контролінгу на вітчизняних підприємствах необхідно застосовувати механізм іiі впровадження. Механізм впровадження системи контролінгу на вітчизняних підприємствах включає: об'єктивні фактори впровадження системи контролінгу; основні інструменті контролінгу (аналіз вихідної ситуації, постановка цілей, ринкові стратегіі, 
функціональні стратегії, оцінка бізнесу, впровадження системи контролінгу (рис. 2). операціоналізація та інші додаткова заходи); етапи
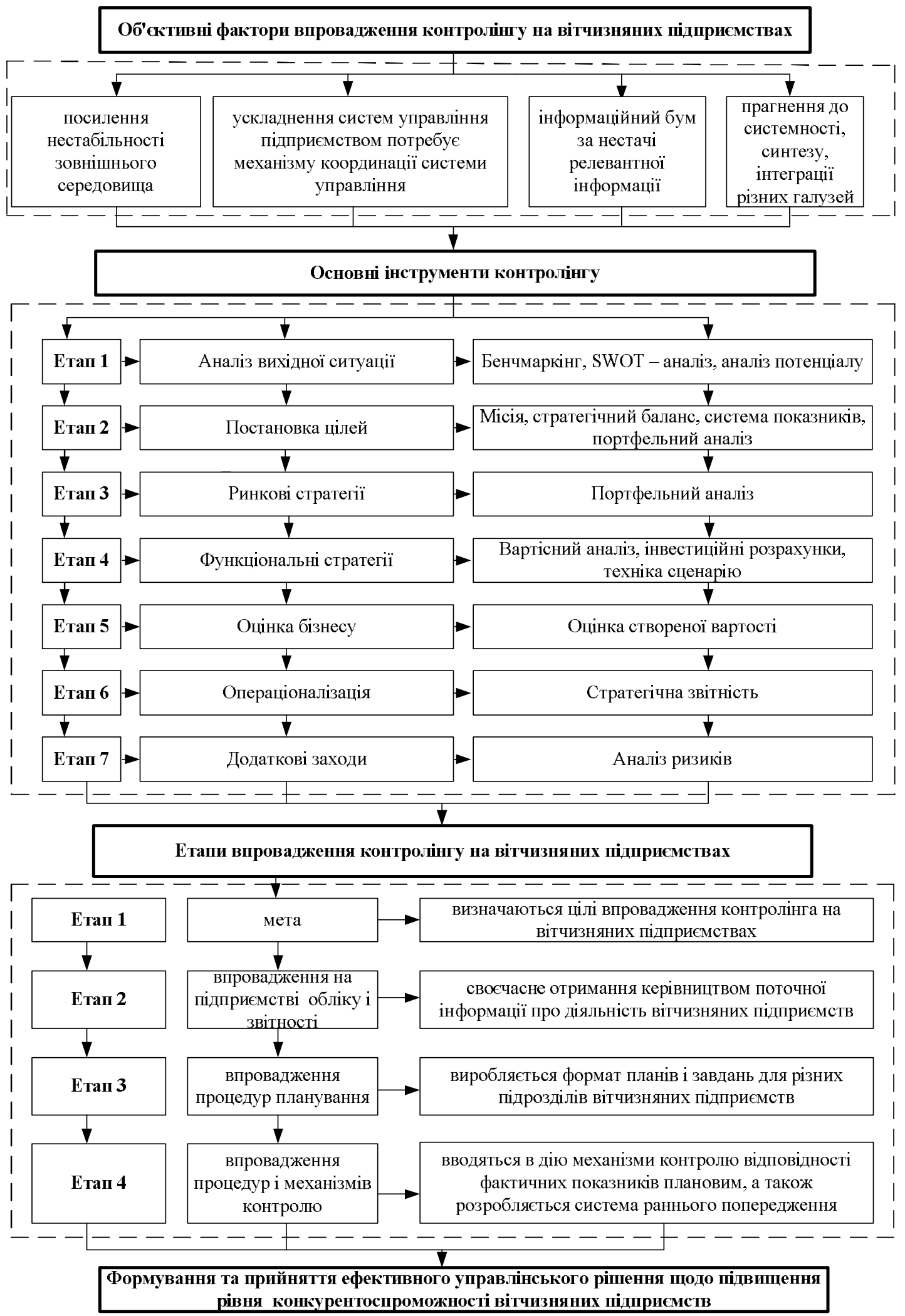

Рис. 2. Механізм впровадження системи контролінгу на вітчизняних підприємствах 
Механізм впровадження системи контролінгу на вітчизняних підприємствах надасть можливість продукувати ефективні управлінські рішення щодо підвищення рівня їх конкурентоспроможності.

$$
\text { Висновки. У сучасних умовах }
$$

господарювання на вітчизняних підприємствах недоліком є відсутність інформації про поточний стан i про перспективи їх діяльності, які потребують ефективного формування нових підходів до управління. Впровадження системи контролінгу на вітчизняних підприємствах надасть можливість досягти успіхів i визнання на вітчизняному та світовому ринках, за рахунок продукування ефективних управлінських рішень. Механізм впровадження системи контролінгу на вітчизняних підприємствах включає в себе оцінку: об'єктивних факторів впровадження контролінгу; інструментів контролінгу; етапів впровадження контролінгу.

\section{СПИСОК ЛІТЕРАТУРИ}

1. Балацкий Е.О. Фінансові потоки у глобальному світі // Механізм регулювання економіки, міжнародний науковий журнал, № 3, т. 1 (35), 2008. - Суми: Університетська книга - С. $173-180$.

2. Веклич О. О. Економічний механізм регулювання контролінгу в Україні / О. Веклич. К.: 2003. -88 c.

3. Давидович I.Є. Контролінг: Навчальний посібник. / I.Є. Давидович. - К.: Центр учбової літератури, 2008. - 552 с.
4. Калайтан Т.В. Контролінг: Навчальний посібник./ Т.В. Калайтан. - Львів: Новий Світ2000, 2008. - 252 c.

5. Портна О. В. Контролінг: навч. посібник / О. В. Портна. - Львів: Магнолія 2006, 2009. $-262 \mathrm{c}$.

6. Пушкар М. Контролінг: Монографія/ М. Пушкар, Р. Пушкар,; М-во освіти і науки України , Терноп. академія народ. господ.. Тернопіль: Карт-бланш, 2004. - 370 с.

7. Савицька Г.В. Економічний аналіз діяльності підприємства: Навчальний посібник./ Г.В. Савицька. - К.: Знання, 2004. - 654 с.

8. Терещенко О. О. Контролінг у системі антикризового управління підприємством / О. О. Терещенко // Фінанси України. - 2001. - № 12. - С. 56-63.

9. Фатхудинов P.A. Конкурентоспособность: экономика, стратегия, управление./ Р.А. Фатхудинов. - М.: ИНФРА - М. 2000.-312 c.

10. Контролінг - від теорії до реалізації на практиці : моногр. / [кол. авт.: В. В. Прохорова, Л. С. Мартюшева, Н. Ю. Петрусевич, Ю. В. Прохорова]; Харківський національний економічний університет. - Харків: ІНЖЕК, 2006.$198 \mathrm{c}$.

11. Чобіток B.I. Управлінні потенціалом конкурентоспроможності промислових підприємств залізничного транспорту на засадах контролінгу : автореф. дис. канд. економ. наук : 08.00.04 - економіка та управління підприємствами (за видами економічної діяльності) / Вікторія Іванівна Чобіток. - X.: 2012. - 24 с.

УДК 330.65

\title{
ФОРМАЛІЗАЦІЯ ПІДХОДІВ ДО ДІАГНОСТИКИ РІВНЯ ФІНАНСОВОЇ БЕЗПЕКИ ПІДПРИЕМСТВ МАШИНОБУДУВАННЯ
}

\author{
Ус Ю.В., к.е.н., доцент (УІІА)
}

У статті визначені проблеми формалізачії підходів до діагностики рівня фінансової безпеки машинобудівних підприємств. Проведений аналіз складу чинників та рівня їх впливу на розвиток підприємств машинобудування в Україні. Визначені стратегічні напрями діяльності машинобудівних підприсмств України.

Ключові слова: фінансова безпека, рівень фінансової безпеки, діагностика, розвиток. 